depths in the deposits. The theoretical aspects of this question and their variations due to previous changes in the physiography of tho areas wero afterwards discussed by Lindgren in various papers published in Economic Geology.

At a later stage in his long career of activity, and based partly on a study of the tin deposits in Bolivia and elsewhere, Lindgren formulated the principles of metasomatism as a process in the formation of oredeposits. This subject he analysed in all its theoretical aspects in his presidential address to tho Geological Society of America in 1925.

Occasional by-products of his main lino of work appeared as descriptions of now mineral species and new occurrences of known forms. Ho was the first to recognize analcite as a primary mineral in igneous rocks, and this led to the necessity of re-examining the colourless, isotropic substances previously assumed to be residual glass in many basalts.

In 1912 Lindgren was appointed professor of economic geology at the Massachusetts Institute of Technology, and in the following year he published the first edition of his comprehensive treatise on "Mineral Deposits". In 1933 he retired from his chair after twenty-one ycars of distinguished service; and Prof. Palache, the eminent mineralogist at Harvard, two years later took the opportunity of giving the name lindgrenite to a new natural molybdate of copper, in the year in which Lindgren received also the honorary D.Se. from Harvard. At "Technology", as the Institute is locally known, Lindgren's name is deeply respected, and is there preserved as the namo given to the library of mining and geology. In 1933 he was elected president of the International Geological Congress, and two years ago the Geological Society of London conferred on him the highest honour at its disposal, the Wollaston medal, which has tho peculiar interest of being struck in palladium, the relatively rare metal first isolated in $\mathbf{1 8 0 2}$ by W. $\mathbf{H}$. Wollaston.

Lindgren's massive record of facts about mineral deposits has been and will be extended by others; but it is unlikely that his theoretical deductions will ever undergo serious change, for he was too wise to stray beyond the deductions immediately justified by the facts, and he know far too much about his subject to regard any present theory of ore deposits to be completo to tho exclusion of all others.

T. H. Holland.

\section{Prof. W. P. Lombard}

The death of Warren Plimpton Lombard at the age of eighty-four years removes one of the last direct links between the laboratory of Carl Ludwig and experimental physiology in the United States-a link with which American physiologists, like those of Britain, have always been proud. Born on May 29, 1855, the son of Israel Lombard by his wife, Mary Ann Plimpton, he was descended on both sides of his family from Puritan stock which had emigrated to the American continent early in the seventeenth century. Ho was born and spent his boyhood in Vest Newton, Massachusetts, and obtained his preparatory education in the public schools of that town. He received his baccalaureate degree from Harvard in 1878; and also an M.D., Harvard, in 1881.

On the advice of Henry Pickering Bowditch, who was a pupil of Ludwig as well as the first experimental physiologist of Harvard, Lombard went to Leipzig in 1881 to spend three years in the stimulating and liberal atmosphere of Carl Ludwig's laboratory. There he became interested in muscular contraction, in spinal reflexes and in the various recording techniques which Ludwig had devised and of which he was an accomplished master. His first paper, published from the Leipzig laboratory, dealt with the sequence of contractions of various muscles of the hind limb of the frog under reflex stimulation (Arch. Anat. u. Physiol., 408; 1885). Ho designed elaborate recording myographs which made possible simultaneous records of as many as twenty muscles attached simultanoously to tho lever system.

Lombard was one of the first after Descartes to consider the problem of reciprocal innervation of antagonistic muscles. Later he studied the lnee-jerk, vasomotor reflexes, skin temperature and its control; and his successor, Robert Gesell, states that much of Lombard's time during his early years was devoted to the study of the mechanics of two-joint muscles (seo Amer. J. Physiol., 20, 1 ; 1907). "The fact that a two-joint muscle can make use of the tendon action of another two.joint muscle on the opposite side of the leg accounts for the paradox that a two-joint muscle, when in a position to have a stronger extensor than flexor leverage, may extend a joint of which it is a flexor". He was likewise interested in respiration and worked out a balance sufficiently sensitive to record the minute changes in weight incident to the fluid loss which accompanied each expiration. His technique for observing capillary circulation in man has been almost universally adopted in the many subsequent studies carried out in this field. As a teacher ho followed Ludwig in being an ardent exponent of 'practical' laboratory instruction, and fow botter laboratory guides have over been written than his "Directions for Laboratory Work in Physiology for the uso of Medical Students (2nd ed. 1914).

On returning to the United States from Europe, Lombard became an assistant in physiology at the College of Physicians and Surgeons in New York City. Thereafter he went back to Europe for several years and on reaching America again in 1889 ho accepted the appointment of assistant professor in physiology at Clark University in Worcester, Massachusetts. In the samo year, William Howell took the chair of physiology at Michigan as successor to Henry Sewall, whoso health had forced him to abandon the inclement weather of Michigan for the clearer and warmer climate of Colorado. Howell was called to Johns Hopkins in 1892 and Lombard was then asked to fill tho chair of physiology at the University of Michigan, where he remained until his wife's death in 1923, at which time he retired.

Lombard was a warm and friendly person, who bad wide interests apart from science, and in the 
years between his retirement and his death he devoted himself to drawing, water-colour painting and etching. Ho spent his summers at Monhegan, Minino, and his friends paid tribute each year to his increasing artistic skill. Shortly beforo his death, he read a paper to a scientific club in Michigan in which he characterized himself in the following terms : "I have always been an optimist and I cannot claim to havo ever been religious. I have thoroughly enjoyed lifo and feel that the finest one can do is to bring pleasures into the lives of others. In this $I$ find a worthy reason for living and shall be glad to live as long as I can enjoy life and help others to do so."

J. F. Forton.
WE regret to announce the following deaths :

Mr. George Eumorfopoulos, the well-known collector of Chinese porcelain and other examples of Oriental art, on December 19, aged seventy-six years.

Prof. Eduard Fischer, professor of botany in the University of Bern from 1897 until 1933.

Senatore Prince Ginori Conti, a well-known Italian industrial chemist, on December 3.

Prof. A. J. Hopkins, emeritus professor of chemistry in Amherst College, known for his work on the early history of seience, on November 10, aged seventy-five years.

\section{NEWS AND VIEWS}

\section{Scientific Research and Technical Development}

AN Advisory Council on Scientific Research and Technical Dovelopment has been sot up by the Minister of Supply to advise him on scientific and technical problems. The main functions of the Council will be to ensure that the work of the Directorato of Scientific Research is carried out with due regard to recent advances in scientific knowledge, to introduce now fields of research and dovelopment, and to make recommendations regarding the most effective use of scientific personnel. The chairman of the Council is Lord Cadman, emeritus professor of mining and petroleum technology in the University of Birmingham, chairman of the Anglo-Iranian Oil Co., Ltd. and of the Iraq Petroleum Co., Ltd. The Admiralty, Air Ministry, and Ministry of Home Security are also represented on tho Council, of which the joint secretaries are Mr. E. T. Paris and Mr. F. Roffey, Ministry of Supply, Adelphi, W.C.2.

The Council is constituted as follows : Prof. E. N. da C. Andrade, professor of physics, University College, London; Dr. E. V. Appleton, secretary, Department of Scientific and Industrial Research; Sir Joseph Barcroft, formerly professor of physiology, University of Cambridge; Prof. W. L. Bragg, Cavendish professor of physics, University of Cam. bridge; Major-General E: M. C. Clarke, director of artillery (military adviser), Ministry of Supply ; Prof. J. D. Cockcroft, professor of natural philosophy, University of Cambridge; Major-General A. E. Davidson, controller of mechanization development (military adviser), Ministry of Supply; Dr. H. J. Gough, director of scientific research, Ministry of Supply ; Dr. H. L. Guy, chief engineer, Mechanical Engineering Department, Metropolitan-Vickers Electrical Co., Ltd. ; Sir Harold Hartley, vice-president and director of research, L.M.S. Railway, and chairman of the Fuel Research Board ; Prof. I. MI. Heilbron, professor of organic chemistry, University of London; Prof. A. V. Hill, secretary, Royal Society, and Foulerton research professor (physiology); Prof.
R. S. Hutton, professor of metallurgy, University of Cambridge; Sir Robert Robertson, director of the Salters' Institute of Industrial Chemistry, formerly Government cliemist ; Sir Robert Robinson, professor of chemistry, University of Oxford ; Mr. J. Rogers, deputy director-general of explosives, Ministry of Supply; Sir Frank Smith, director of instrument production, Ministry of Supply, director of research, Anglo-Iranian Oil Co.; Prof. R. V. Southwell, professor of engineering, University of Oxford; Prof. G. I. Taylor, Yarrow research professor of the Royal Society (engineering); Sir Maurice Taylor, senior military adviser, Ministry of Supply; Sir Henry Tizard, rector of Imperial College of Science, chairman, Aeronautical Research Committeo.

\section{Early Man and his Forerunners}

Is the two years 1937-39 a series of researches carried out by P. Teilhard do Chardin, Prof. Franz Weidenreich and their fellow-workers of the Cenozoic Research Laboratory of the Geological Survey of China, papers on which have only just reached Great Britain (see Nature, December 23, p. 1054 and December 30, p. 1097) has made a notable contribution to anthropological study, not merely in so far as it deals with early man in China, but also in its bearing upon fundamental problems of the development of the human stock and the origin and distribution of its varieties. How far Teilhard do Chardin's suggested need for a revision of Tertiary and Quaternary classification in geology and palæontology will bo accepted as of general application may remain in abeyance for the moment; but his brilliant synthetic study of recent geological and palæontological discovery provides a new diagnosis -in China at least-for the much-debated division between Pliocene and Pleistocene in the form of the definite break, almost catastrophic in its proportions, in fauna and physiographic conditions between the Nihowan and Choukoution phases of the so-called Sanmenian, which is followed by the appearance of man, who in some sort, it may be suggested, now might bo regarded as a characteristic fosail. 